\title{
ESTÁGIO SUPERVISIONADO: UMA RELAÇÃO ENTRE UNIVERSIDADE E ESCOLA BÁSICA
}

Geovanni Mendes Amancio, Universidade Federal de Campina Grande (UFCG), geovanniamancio@gmail.com

Raquel Evelly Vieira de Araújo, Universidade Federal de Campina grande (UFCG), raquelevelly75@gmail.com

Joseane Abílio de Sousa Ferreira, Universidade Federal de Campina Grande (UFCG), joseaneabilio@hotmail.com

PALAVRAS-CHAVE: Interação; Integração; Instrução.

\section{INTRODUÇÃO}

O presente trabalho remete-se a uma sucinta descrição de como acontece a interação das Universidades junto às escolas de ensino básico, tendo como zona de contato, ou seja, o fator de junção entre os referidos âmbitos, o estágio supervisionado. Este, é de suma importância, uma vez que, é por intermédio dele que se tem uma das poucas relações entre os itens acima mencionados, e, também, somente nele, é possível que o licenciando tenha contato direto com a realidade do seu futuro ambiente de trabalho. Assim, já inicia-se uma avaliação do licenciando sobre o âmbito escolar, percebendo que a situação e a organização desse espaço não condiz com as informações apresentadas atualmente.

\section{METODOLOGIA}

Utilizou-se de pesquisa bibliográfica, partindo de fontes que tratam do estágio supervisionado, mas que não focam diretamente nas relações que este apresenta, formulando assim, somente ideias homogêneas. Através do levantamento bibliográfico poderemos observar como o estágio supervisionado atua nessa relação Universidade e escola do ensino básico, com quê proporção ele influência, qual o campo onde se realiza, e por fim, os benefícios e/ou malefícios dessa relação. 


\section{DISCUSSÕES, RESULTADOS E INTERPRETAÇÕES}

Algumas pesquisas mostram que, na maior parte dos eventos, os trabalhos científicos sempre são mais voltados para os temas específicos dos cursos e poucos são os que abordam a temática do estágio supervisionado nas licenciaturas. Desta feita, este trabalho consta uma perspectiva nova para com a interdisciplinaridade entre universidade e escola, e a partir desta, as relações nas áreas de ensino e pesquisa; e, professor do ensino básico e licenciando, relacionando-as.

Iniciando pela a relação universidade e escola básica, Santos (2013) explica que o estágio supervisionado possibilita ao discente a adequação interacional através da prática, trilhando o caminho do licenciando para sua formação quanto profissional sobre as condições determinadas pelo docente/orientador. O estágio em si contribui para que as universidades deem espaço ao discente, para que o mesmo conviva e analise a necessidade em torno de sua formação.

Pode-se notar que a universidade necessita da escola básica e vice-versa, pois, a escola funciona como campo de pesquisa para a universidade e, a universidade como ensino para a escola, estabelecendo assim, uma constante relação. Para entendermos melhor essa relação, Chervel (1990) afirma que a escola:

[...] é, em cada época, tributária de um complexo de objetivos que se entrelaçam e se combinam numa delicada arquitetura da qual alguns tentaram fazer um modelo. É aqui que intervém a oposição entre educação e instrução. $\mathrm{O}$ conjunto dessas finalidades consigna a escola sua função educativa. Uma parte somente entre elas obriga a dar uma instrução. Mas essa instrução está inteiramente integrada ao esquema educacional que governa o sistema escolar, ou ramo estudado [...] (p.188).

Num segundo momento, Cavalcanti (2006, p. 46-47), direcionado a relação ensino e pesquisa, enfatizando teoria e prática, na formação inicial, sugere que deve-se "articular teoria e prática; integrar ensino e pesquisa; atentar para as diferentes capacidades e habilidades requeridas para o trabalho profissional e promover a continuidade da profissionalização", assim, segundo Santos (2013), os professores devem ser críticos e criativos exercendo a docência, e, buscarem concordância entre ensino e pesquisa.

Por fim, na relação professor do ensino básico e licenciando, é possível observar que o primeiro por ser reconhecido no ambiente de trabalho auxilia o segundo enquanto este ministra a aula, exercendo seu cargo como estagiário. Podemos explicar melhor essa relação, utilizando o Parecer 28/2001 (BRASIL, 2001b, p.10), que diz: “[...] o estágio curricular 
supervisionado supõe uma relação pedagógica entre alguém que já é um profissional reconhecido em um ambiente institucional de trabalho e um aluno estagiário”.

\section{CONSIDERAÇÕES FINAIS}

Partindo do que vimos no decorrer do trabalho, conclui-se que o estágio supervisionado relaciona de maneira constante universidade e as escolas do ensino básico e cria um elo entre elas, seja em qualquer uma das relações supracitadas acima. Através do estágio, podem fluir outros tipos de relações entre academia e escola, como por exemplo, atividades extracurriculares, mais especificamente projetos de extensão, visando mais uma vez usar a pesquisa universitária como ensino, e através deste iniciar novas pesquisas.

\section{REFERÊNCIAS}

CAVALCANTI, L. de S. Geografia escolar na formação e práticas docentes: o professor e seu conhecimento geográfico. Encontro Nacional de Didática e Prática de Ensino. Recife: ENDIPE, 2006.

CHERVEL, A. História das disciplinas escolares: reflexões sobre um campo de pesquisa. Teoria e educação, Porto Alegre, n' .02 , p.188, 1990.

SANTOS, M. F. P. dos. O estágio supervisionado na formação dos professores de Geografia. In: ALBUQURQUE, M. A. M. de; FERREIRA, J. A. de S. Org.(s). Formação, Pesquisas e Práticas Docentes: Reformas Curriculares em Questão. João Pessoa: ed. Mídia, 2013. p. 59-86.

BRASIL, 2001, PARECER CNE/CP 9/2001 - HOMOLOGADO - Despacho do Ministro em 17/1/2002, publicado no Diário Oficial da União de 18/1/2002, Seção 1, p. 31. 